\title{
Exploration, phenolic content determination, and antioxidant activity of dominant pteridophytes in Gunung Malang Village, Mount Halimun Salak National Park, Indonesia
}

\author{
RINDITA $^{1}$, VIVI ANGGIA ${ }^{1,2, \vartheta}$, EKA RAHMAESA ${ }^{1}$, RETNA KUSUMA DEVI ${ }^{1}$, LIDIA FATMAH ALAWIYAH ${ }^{1}$ \\ ${ }^{1}$ Department of Pharmacognosy and Phytochemistry, Faculty of Pharmacy, Universitas Muhammadiyah Prof. Dr. HAMKA, Jakarta 13460, Indonesia. \\ Tel.: +62-21-8611070, Fax.: +62-21-86603233, "email : vivi.anggia@gmail.com \\ ${ }^{2}$ Department of Pharmacognosy and Phytochemistry, Faculty of Health Sciences, Universitas Islam Negeri Syarif Hidayatullah Jakarta. Jl. Ir. H. Juanda \\ No. 95, Cempaka Putih, Tangerang Selatan 15412, Banten, Indonesia
}

Manuscript received: 17 June 2020. Revision accepted: 22 July 2020.

\begin{abstract}
Rindita, Anggia V, Rahmaesa E, Devi RK, Alawiyah LF. 2020. Exploration, phenolic content determination, and antioxidant activity of dominant pteridophytes in Gunung Malang Village, Mount Halimun Salak National Park, Indonesia. Biodiversitas 21: 36763682. Pteridophytes have been known to have pharmacological activities as an antioxidant, anti-inflammation, antimicrobials, and anticancer, such as Selaginella sp. In this research, exploration was conducted in Gunung Malang Village, Mount Halimun Salak National Park (TNGHS), West Java. Samples were collected by purposive sampling method, related to its abundant populations, Histiopteris incisa, Nephrolepis biserrata, and Selaginella willdenowii were collected based on different height and light intensity. Abiotic factors were measured to know their ecological requirements. Samples were extracted using ultrasonic method. Organoleptic test, yield, and phytochemical screening were done for the crudes extract. Total phenolic level was determined with Folin-Ciocalteu method and antioxidant activity test with DPPH. Phytochemical screening showed that $H$. incisa contains phenolics, saponins, tannins, and steroids; $N$. biserrata contains phenolics, flavonoids, and saponins while $S$. willdenowii contains phenolics, alkaloids, flavonoids, saponins, and tannins. Phenolic content of $H$. incisa and $N$. biserrata from $700 \mathrm{~m}$. asl.was $9.8523 \mathrm{mg}$ GAE/g $\pm 0.9694 \mathrm{and} 17.5399 \mathrm{mg}$ $\mathrm{GAE} / \mathrm{g} \pm 0.5350$ respectively, from $1000 \mathrm{~m}$. asl. was $18.1231 \mathrm{mgGAE} / \mathrm{g} \pm 2.1535$ and $8.8468 \mathrm{mg} \mathrm{GAE} / \mathrm{g} \pm 0.1437$. S. willdenowii extract collected from shaded canopy forest was $19.2324 \mathrm{mg} \mathrm{GAE} / \mathrm{g} \pm 0.6041$ and opened canopy forest was $38.7087 \mathrm{mg} \mathrm{GAE} / \mathrm{g} \pm 1.484$. Antioxidant $\mathrm{IC}_{50}$ of $\mathrm{H}$. incisa and $\mathrm{N}$. biserrata from $700 \mathrm{~m}$. asl. respectively was $96.4271 \mathrm{ppm}$ and $85.1907 \mathrm{ppm}$, while from $1000 \mathrm{~m}$. asl. was $75.6381 \mathrm{ppm}$ and $95.0678 \mathrm{ppm}, S$. willdenowii from the closed canopy is $101.7326 \mathrm{ppm}$, while from the opened canopy was $92.0998 \mathrm{ppm}$. This study shows that all ferns tested gave significant antioxidant activity and was influenced by environmental factors.
\end{abstract}

Keywords: Antioxidant activity, Histiopteris incisa, Nephrolepis biserrata, phenolic content, Selaginella willdenowii

\section{INTRODUCTION}

Indonesia is one of the ASEAN countries that have the greatest biological wealth and has the second-highest number of indigenous medicinal plants, after the Amazon rain forests (Elfahmi et al. 2014). Its biodiversity is a potential source in the exploration of beneficial compounds. Exploration of medicinal plants in their natural habitat is an alternative search for medicinal plants which is useful for finding medicinal raw materials. Based on a survey done in Mount Halimun Salak National Park (Taman Nasional Gunung Halimun Salak/TNHGS), it is known that there are many large groups of plants, one of which is ferns. Only very few explorations of beneficial natural compounds done on Indonesian ferns even though the amount is very abundant in nature. Approximately 12000-15000 kinds of ferns spread across the world (Roos 1996). However, ferns not only abundantly found inside the forest but also in damaged sites, since its presence may be regarded as an alert of ecological disturbances (Dai et al. 2020).

Ferns have been uses from ancient times to treat various illnesses throughout the world (Raimana et al. 2011).
Several studies have been carried out to explore the pharmacological activities of ferns. Various secondary metabolites were reported as active components mostly belonging to the terpenoid group (triterpenoids, diterpenoids, sesquiterpenoids), phenolic group (phenylpropanoid derivatives and others), flavonoid, and alkaloid (Keller and Prance 2015). Ferns contain various secondary metabolites with therapeutically-relevant bioactivities, including anti-cancer, antioxidant, and antiinflammatory activities (Raimana et al. 2011). Some active compounds from ferns have been shown to provide beneficial pharmacological activities. Angiopteroside from Angiopteris evecta showed active against Bacillus subtilis and significant activity to inhibit the growth of HIV-1 Reverse transcriptase (Anggia et al. 2015). Phenolic compounds from Trichomanes chinense are shown to provide significant antibacterial activity (Syafni et al. 2012). The water extract of Cheilanthes farinosa was found to have antiproliferative and apoptotic activity in human liver cancer cells (Radhika 2010).

Ferns tend to live in humid tropical areas and Indonesia is one of the places to find various types of ferns. Based on the surveys carried out in Mount Halimun Salak National Park, western Java, Indonesia it was observed that there are 
several dominant populations species of ferns occupied the area i.e Selaginella willdenowii, Histiopteris incisa, and Nephrolepis biserrata. S. willdenowii extract was reported to contain flavonoids 4', 7"-di-O-metilamentoflavone, isocriptomerin, and 7"-O-methylrobusta-flavone which were significantly cytotoxic against various cancer cells (Silva et al. 1995). The traditional use of its ferns is not to be a novelty in different countries. One of the subtribes in Ifugao, Philipines used crushed leaves of $H$. incisa to treat burns (Balangcod 2011). Besides consumed as a vegetable, $N$. biserrata has been used traditionally to treat boils, abscesses, and blisters (Rani 2010). and in the African region, this fern is commonly used to treat malaria (Koudouvo 2011). Selaginella is useful for traditional medicine, especially for treating wounds, postpartum, menstrual disorders and body fit improvement (tonics) (Setyawan 2016). Unfortunately, not many references discuss the constituents of $N$. biserrata and $H$. incisa, so it will be interesting to study bioactive compounds and their pharmacological activities.

Phenolic compounds are natural products that are widely used today. Their biological activities provide a major role in human interests. There some report on the activity of phenolic compounds and its derivates for health benefit especially to inhibit free radicals, peroxide decomposition, metal inactivation or oxygen scavenging in biological systems, and prevent oxidative disease (Babbar 2015). Various studies have proven that both biotic and abiotic factor from the environment in which plants grow will affect their growth and the chemical compounds produced. Sulasmi et al. (2019) found that four fern species in Baluran National Park have different types and content of flavonoids. The environmental factors, such as light intensity and altitude, irradiation factors will affect the growth and development of plants, thereby regulating the biosynthesis of secondary metabolites. In this study, phenolic content levels and antioxidant activity of $S$. willdenowii, $H$. incisa, and $N$. biserrata found in different places, altitude and sun exposure in Gunung Halimun National Park (TNGHS) will be reported.

\section{MATERIALS AND METHODS}

\section{Material}

\section{Plant collection and authentication}

Histiopteris incisa, N. biserrata, and S. willdenowii collected from Gunung Malang Village, Gunung Halimun Salak National Park (TNGHS) in August 2020 and subjected to determination process at Research Center for Biology, Indonesian Institute of Sciences, Cibinong, Bogor,
Indonesia. Samples were taken based on differences in forest vegetation that is shaded and open forests and differences altitude between 700 and $1,000 \mathrm{~m}$. asl. Administratively, Gunung Malang Village is included in Bogor District, West Java Province, Indonesia

\section{Chemical and reagents}

Folin-Ciocalteau, 2.2-diphenylpicrylhydrazyl (DPPH), gallic acid, were purchased from Sigma Aldrich and other chemical reagents used in this research were analytical grade.

\section{Methods}

Determination of environmental parameters

Environmental parameters of the location are determined i.e light intensity, air humidity, air temperature using 4-in-1 digital weather meter; soil $\mathrm{pH}$, and moisture using soil tester digital and determination of coordinates using a GPS device.

\section{Extraction}

$150 \mathrm{~g}$ of powdered leaves of each fern were extracted with ethanol using ultrasonic method with $15 \mathrm{~L}$ of $70 \%$ ethanol at intervals of 30 minutes and repeated several times until the extraction was completely marked by colorless filtrate. Each resulting extracts were filtered and evaporated in vacuo with rotary evaporator at $50^{\circ} \mathrm{C}$ to yield concentrated extract of ferns (Table 1).

\section{Phytochemical screening}

Concentrated extracts were diluted using ethanol and identified qualitatively for the presence of alkaloid, flavonoid, tannin, terpene, steroid, and saponin (Tiwari et al. 2011).

\section{Determination of phenolic compound level}

Determination of total phenolic levels of ferns extracts was done using Folin-Ciocalteu method performed by Stankovic et al. (2011) with a few of modification. Ferns leaves extract $0.5 \mathrm{ml}(1000 \mathrm{ppm}), 2 \mathrm{ml}$ Folin Ciocalteu and $4 \mathrm{ml} \mathrm{Na} \mathrm{CO}_{3} 1 \mathrm{M}$ reagent were mixed homogeneously. The mixed solution was incubated in operating time range that has been determined before by observed the absorbance of gallic acid in the range of 1 to 120 minutes and determined the time that provides stable absorbance which is obtained at 100 minutes. All determination was carried out in triplicate and the phenolic level obtained was counted as equivalent to gallic acid. The standard calibration curve determined from the linear regression equation between series concentrations of gallic acid (x) and the absorbance obtained from reaction with Folin-Ciocalteu reagent $(\mathrm{y})$ (Stankovic et al. 2011).

Table 1. Extraction yield of each fern extract

\begin{tabular}{lcccccc}
\hline & \multicolumn{2}{c}{ Histiopteris incisa } & \multicolumn{2}{c}{ Nephrolepis biserrata } & \multicolumn{2}{c}{ Selaginella willdenowii } \\
\hline Habitat & 700 & 1000 & 700 & 1000 & Open & Shaded \\
& $\mathrm{m}$. asl & $\mathrm{m}$. asl & $\mathrm{m}$. asl & m. asl & forest & forest \\
Extraction yield & $19.58 \%$ & $21.91 \%$ & $23.97 \%$ & $19.71 \%$ & $25.90 \%$ & $26.90 \%$ \\
\hline
\end{tabular}




\section{Determination of antioxidant activity}

Determination of antioxidant activity was carried out according to the method of Molyneux (2004). Two mg of DPPH dissolved in $100 \mathrm{ml}$ of $\mathrm{MeOH}$, then $3.8 \mathrm{ml}$ of DPPH solution and $0.2 \mathrm{~mL}$ of $\mathrm{MeOH}$ was added and left for 30 minutes in the darkroom. The absorbance was measured with a UV-Vis spectrophotometer (at 400-800 nm) to obtain the wavelength of maximum absorbance $\left(\lambda_{\max }\right)$. Each sample was diluted with $\mathrm{MeOH}$ to prepare extracts with concentrations of $20,40,60,80$, and $100 \mathrm{ppm}$. $1 \mathrm{ml}$ of each concentration was pipetted into a test tube, then $3 \mathrm{ml}$ of DPPH solution of $0.887 \mathrm{mM}$ was added, shaken, and allowed to stand for 30 minutes. Absorbance was measured at $516 \mathrm{~nm}$. Gallic acid was used as a positive control (Molyneux 2004).

\section{RESULTS AND DISCUSSION}

Botanical determination is the first step in research to ensure the truth of plant species. Verification of specimen identity was carried out at the Indonesian Institute of Sciences (LIPI) Biology Research Center, Cibinong, Bogor. The results of verification of these specimens were $H$. incisa, N. biserrata, and S. willdenowii.

\section{Determination of environmental parameters}

Based on the data of survey obtained it was found that $H$. incisa and $N$. biserrata were grown at a different altitude between 700 and $1000 \mathrm{~m}$. asl, meanwhile $S$. willdenowii was found both in shaded and open forest areas in Gunung Malang Village, Gunung Halimun Salak
National Park. The aim of pursuing the environmental parameters is to determine the relationship between environmental factors with their chemical constituents and antioxidant activity. Environmental parameters measured were light intensity, air humidity, air temperature, soil $\mathrm{pH}$, moisture, and coordinates of each found ferns species. The result can be seen in Tables 2 and 3 .

\section{Organoleptic}

Histiopteris incisa has large, black rhizomes and root fibers spread along the rhizomes, upright stem, brownish yellow, rounded, shiny and covered with fine hairs along the stem. The leaves have different shapes, sizes and arrangements. Generally, the leaves are arranged in double triple pinnate compounds (tripinnate), dark green, roughtextured, and stiff. Pina facing and having the same distance, sporangium is located in the abaxial part of the leaf. Young plants that curl can come out of the roots or are at the ends of the stems of adult plants. Young leaves that are curled light green and covered with fine white hairs (Figure 1) (Purnawati 2014).

Nephrolepis biserrata is an epiphyte plant that has a narrow and thinly spread scale morphology, the edges of the scales have fine hair. When young, pale green scales, when old, brown scales with pale brown edges, while scales that are on greedily scattered and are very small in size. The distinctive feature of the $N$. biserrata fern is located on the scales on the stip and the location of the sorus close to the edge of the medial pinna (Figure 2) (De Winter and Amoroso 2003).

Table 2. Environmental parameter of Histiopteris incisa and Nephrolepis biserrata in difference height

\begin{tabular}{|c|c|c|c|c|}
\hline \multirow{2}{*}{ Parameters } & \multicolumn{2}{|c|}{700 m.asl } & \multicolumn{2}{|c|}{1000 m.asl } \\
\hline & H. incisa & N. biserrata & H. incisa & N. biserrata \\
\hline Light intensity (LUX) & $112-1,851$ & $914-7,980$ & $2,390-4,920$ & $1,526-8,456$ \\
\hline Air humidity (\% RH) & $58.2-68.5$ & $58.1-71.3$ & $55.4-69.4$ & $55.4-69.4$ \\
\hline Air temperature $\left({ }^{\circ} \mathrm{C}\right)$ & $25.0-28.6$ & $26.9-29.2$ & $24.1-29.8$ & $24.1-29.8$ \\
\hline Soil temperature $\left({ }^{\circ} \mathrm{C}\right)$ & $21-23$ & $22-23$ & $22-23$ & $21-23$ \\
\hline Soil pH & 7.0 & 7.0 & 7.0 & 7.0 \\
\hline Soil humidity (\%) & $20-30$ & 40 & $25-40$ & $25-40$ \\
\hline & EL: $106^{\circ} 43^{`} 22,1^{\prime \prime}$ & EL 106'43'22.1'” & EL: $43^{\circ} 31^{\prime} 5^{\prime \prime}$ & EL: $106^{0} 31^{\prime} 5^{\prime \prime}$ \\
\hline
\end{tabular}

Table 3. Environmental parameter of Selaginella willdenowii vegetation in shaded and exposed forest

\begin{tabular}{lll}
\hline Environmental parameters & Shaded & Exposed \\
\hline Altitude & $908 \mathrm{~m}$. asl & $1,050 \mathrm{~m}$. asl \\
Light intensity $(\mathrm{LUX})$ & $670-4,280$ & $5,490-20,000$ \\
Air humidity $(\% \mathrm{RH})$ & $57.9-67.3$ & $38.9-65.0$ \\
Air temperature $\left({ }^{\circ} \mathrm{C}\right)$ & $25.0-27.6$ & $28.2-37.5$ \\
Soil temperature $\left({ }^{\circ} \mathrm{C}\right)$ & $20-21$ & $22-25$ \\
Soil pH & 7 & $6.0-6.7$ \\
Soil humidity $(\%)$ & $15-35$ & $10-30$ \\
Coordinate & $\mathrm{S} 06^{\circ} 40^{\prime} 50,6^{\prime \prime} ; \mathrm{E} 106^{\circ} 41^{\prime} 11,33^{\prime}$, & $\mathrm{S} 06^{\circ} 40^{\prime} 57^{\prime \prime} ; \mathrm{E} 106^{\circ} 43^{\prime} 32^{\prime}{ }^{\prime}$ \\
\hline
\end{tabular}




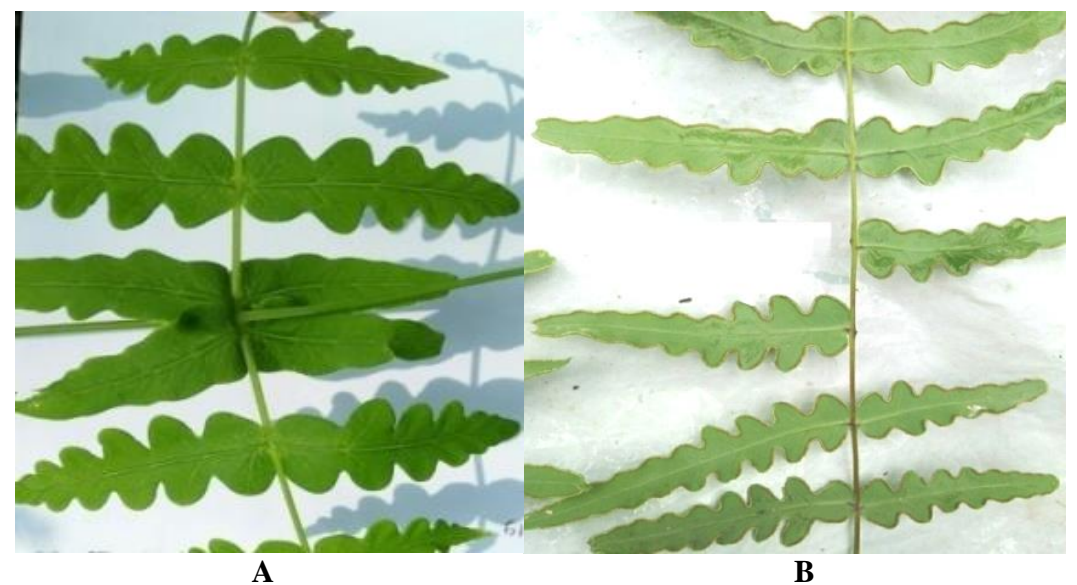

Figure 1. Leaf shape of Histiopteris incisa

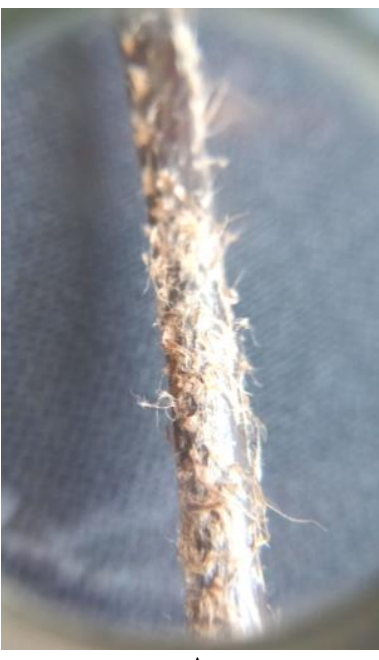

A

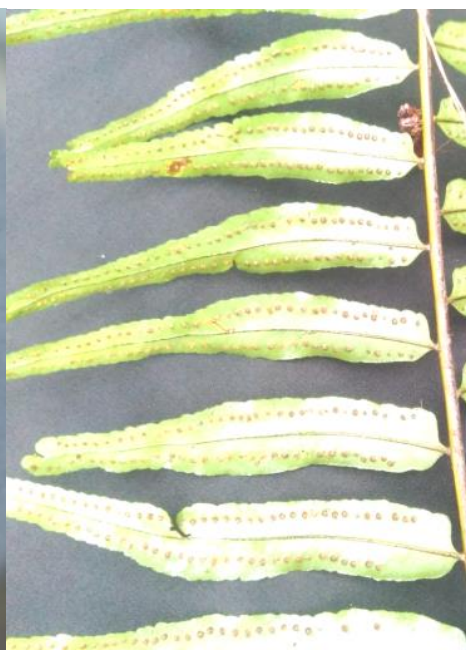

B

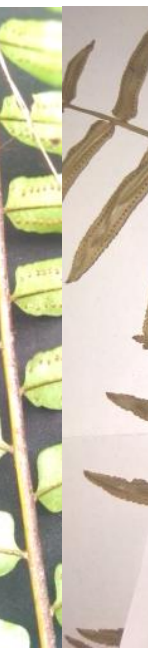

T. I

Figure 2. Plant morphology of Nephrolepis biserrata. A. Scales, B. Sorus, C. Lamina, D. Rachis

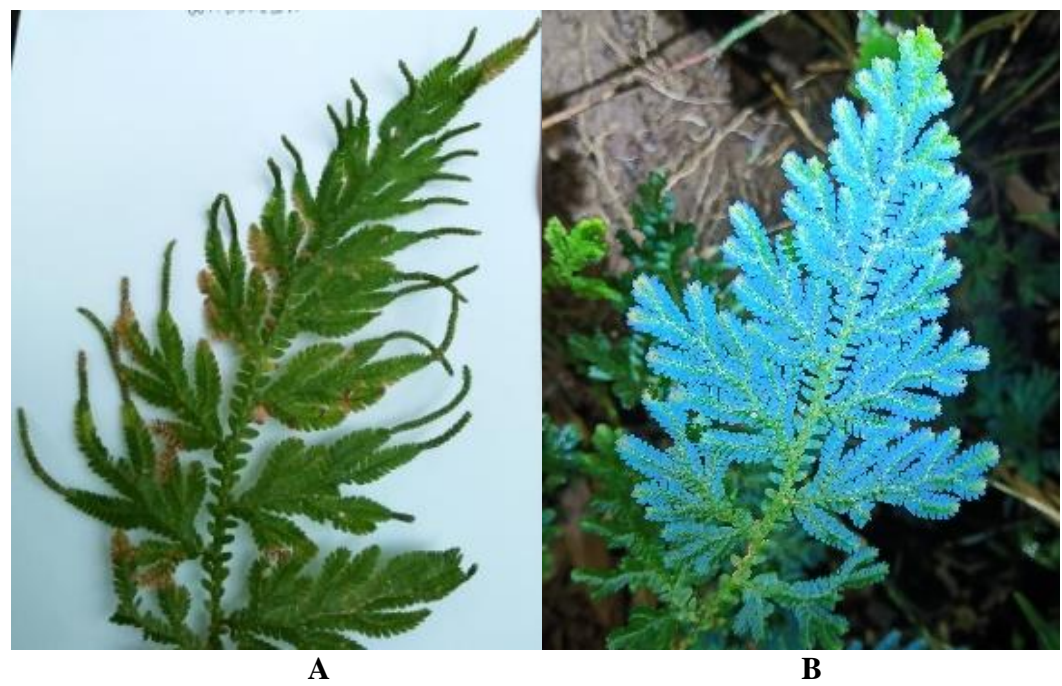

Figure 3. Plant morphology of Selaginella willdenowii A. Leaves in open forest; B. Leaves in shaded forest 
Selaginella willdenowii is a climbing herb plant, 1-5 m long. The stems, at the bottom of the leaves line 4 , the distance from one another is far apart. Leaves from the front row are very small, attached to the stem, leaves from both sides are larger, spaced wide, easily fall out, form a weak sickle. Fertile ovary leaves are wide, with a short pointed tip, tightly crammed into ears with a length of 0.5 $2.5 \mathrm{~cm}$ (Steenis 2013) (Figure 3).

Phytochemical screening

The preliminary phytochemical screening of the ethanolic extract of the leaves of $H$. incisa, $N$. biserrata, and $S$. willdenowii leaves extract were presented in Table 4.

\section{Determination of phenolic content level}

Levels of phenolic content of $H$. incisa, $N$. biserrata, and $S$. willdenowii leaves extract obtained from different ecological factors were determined to analyze the influence of environmental factors on their chemical content. Phenolic content was determined with Uv-Vis spectrophotometry method at wavelength of $759.5 \mathrm{~nm}$ using Follin Ciocalteu reagent and gallic acid as a standard. Phenolic content of each fern extract is shown in Table 5.

\section{Determination of antioxidant activity}

Antioxidants activity of $H$. incisa, N.biserrata, and $S$. willdenowii leaves extract were determined by using DPPH following the method of Molyneux (2004); and experiment was done in triplicate. The samples were measured at 516 $\mathrm{nm}$ with absorbance of DPPH was 0.790. Antioxidant properties of each sample are shown in Table 6.

Table 4. Phytochemical screening of Histiopteris incisa, Nephrolepis biserrata and Selaginella willdenowii leaves extract

\begin{tabular}{lcccccc}
\hline Chemical & \multicolumn{2}{c}{ H. incisa } & \multicolumn{2}{c}{ N. biserrata } & \multicolumn{2}{c}{ S. willdenowii } \\
\cline { 2 - 7 } analysis & $\mathbf{7 0 0}$ & $\mathbf{1 0 0 0}$ & $\mathbf{7 0 0}$ & $\mathbf{1 0 0 0}$ & Open & $\begin{array}{c}\text { Shaded } \\
\text { f. asl }\end{array}$ \\
& m. asl & m. asl & m. asl & forest & forest \\
\hline Alkaloid & - & - & - & - & + & + \\
Phenol & + & + & + & + & + & + \\
Flavonoid & - & - & + & + & + & + \\
Tanin & + & + & - & - & + & + \\
Saponin & + & + & + & + & + & + \\
Triterpene & + & + & - & - & - & - \\
Steroid & + & + & - & - & + & + \\
\hline
\end{tabular}

Table 6. Antioxidant properties of Histiopteris incisa, Nephrolepis biserrata and Selaginella willdenowii leaves extract

\begin{tabular}{|c|c|c|c|}
\hline Samples & $\begin{array}{l}\text { Conc. } \\
\text { (ppm) }\end{array}$ & $\begin{array}{l}\text { Inhibition (\%) } \\
(\text { Mean } \pm \text { SD) }\end{array}$ & $\begin{array}{l}\text { IC50 } \\
(\text { ppm) }\end{array}$ \\
\hline \multicolumn{4}{|l|}{ H. incisa } \\
\hline \multirow[t]{5}{*}{$700 \mathrm{~m}$. asl } & 20 & $0.2352 \pm 0.0002$ & 96.4271 \\
\hline & 40 & $22.0253 \pm 0.1266$ & \\
\hline & 60 & $26.2023 \pm 0.0002$ & \\
\hline & 80 & $37.5105 \pm 0.0730$ & \\
\hline & 100 & $53.2911 \pm 0.6698$ & \\
\hline \multirow[t]{5}{*}{$1000 \mathrm{~m}$. asl } & 20 & $19.3672 \pm 0.0003$ & 75.6381 \\
\hline & 40 & $25.5695 \pm 0.0004$ & \\
\hline & 60 & $38.5232 \pm 0.0731$ & \\
\hline & 80 & $54.3461 \pm 0.0734$ & \\
\hline & 100 & $65.1477 \pm 0.0731$ & \\
\hline \multicolumn{4}{|l|}{ N. biserrata } \\
\hline \multirow[t]{5}{*}{$700 \mathrm{~m}$. asl } & 20 & $0.3795 \pm 0.0004$ & 85.1907 \\
\hline & 40 & $11.0267 \pm 0.1289$ & \\
\hline & 60 & $32.5738 \pm 0.7309$ & \\
\hline & 80 & $45.8649 \pm 0.3654$ & \\
\hline & 100 & $61.3922 \pm 0.0002$ & \\
\hline \multirow[t]{5}{*}{$1000 \mathrm{~m}$. asl } & 20 & $2.9957 \pm 0.6371$ & 95.0678 \\
\hline & 40 & $14.8100 \pm 1.4598$ & \\
\hline & 60 & $25.8649 \pm 0.5269$ & \\
\hline & 80 & $40.4219 \pm 0.3867$ & \\
\hline & 100 & $54.0084 \pm 2.266$ & \\
\hline \multicolumn{4}{|l|}{ S. willdenowii } \\
\hline \multirow[t]{5}{*}{ Open forest } & 20 & $2.4052 \pm 0.0003$ & 92.0998 \\
\hline & 40 & $12.7004 \pm 0.0731$ & \\
\hline & 60 & $30.8860 \pm 0.0127$ & \\
\hline & 80 & $43.9240 \pm 1.2929$ & \\
\hline & 100 & $53.1645 \pm 0.1934$ & \\
\hline \multirow[t]{5}{*}{ Shaded forest } & 20 & $2.3004 \pm 0.0003$ & 101.7326 \\
\hline & 40 & $11.7722 \pm 0.0003$ & \\
\hline & 60 & $24.9363 \pm 0.0004$ & \\
\hline & 80 & $34.1773 \pm 0.0004$ & \\
\hline & 100 & $51.2657 \pm 0.2657$ & \\
\hline \multirow[t]{5}{*}{ Gallic acid } & 2 & $17.0885 \pm 0.1266$ & 7.9819 \\
\hline & 4 & $28.3121 \pm 0.9832$ & \\
\hline & 6 & $37.1308 \pm 0.0730$ & \\
\hline & 8 & $49.8312 \pm 0.5981$ & \\
\hline & 10 & $62.2363 \pm 0.0730$ & \\
\hline
\end{tabular}

Note: Conc.: Concentrations

Table 5. Phenolic compound analysis of Histiopteris incisa, Nephrolepis biserrata, and Selaginella willdenowii leaves extract

\begin{tabular}{lcccc}
\hline Sample & \multicolumn{3}{c}{ Phenolic content(mg GAE/g) } & Mean \pm SD \\
\cline { 2 - 4 } & $\mathbf{1}$ & $\mathbf{2}$ & $\mathbf{3}$ & \\
\hline H. incisa & 8.7709 & 10.1430 & 10.6432 & $9.8523 \mathrm{mg} \mathrm{GAE} / \mathrm{g} \pm 0.9694$ \\
$700 \mathrm{~m}$. asl & 16.1390 & 17.8173 & 20.4132 & $18.1231 \mathrm{mg} \mathrm{GAE} / \mathrm{g} \pm 2.1535$ \\
1000 m.asl & & & & \\
$N$. biserrata & & & \\
700 m.asl & 18.0805 & 17.5288 & 17.0106 & $17.5399 \mathrm{mg} \mathrm{GAE} / \mathrm{g} \pm 0.5350$ \\
1000 m.asl & 8.7984 & 8.7336 & 9.0085 & $8.8468 \mathrm{mg} \mathrm{GAE} / \mathrm{g} \pm 0.1437$ \\
& & & & \\
S. willdenowii & & & & \\
Open canopy forest & 36.9999 & 39.6766 & 39.4498 & $38.7087 \mathrm{mg} \mathrm{GAE} / \mathrm{g} \pm 1.484$ \\
Shaded canopy forest & 18.5348 & 19.5823 & 19.5800 & $19.2324 \mathrm{mg} \mathrm{GAE} / \mathrm{g} \pm 0.6041$ \\
\hline
\end{tabular}




\section{Discussion}

Indonesia, having a humid tropical climate is a good place to live for various ferns, one of the locations is Gunung Halimun Salak National Park. Based on observational data in the field it appears that all of the ferns studied can grow well in there. It was observed that the different ecological sites of ferns gave different physicochemical parameters. It was also noticed that $H$. incisa and $N$. biserrata found in open and in shaded forest locations with different altitudes between 700 and $1000 \mathrm{~m}$. asl and S. willdenowii appeared to be two different vegetation ecotypes.

The presence and amount of phytochemical constituents are influenced by several factors both internal factors such as genes and external factors such as light, temperature, humidity, $\mathrm{pH}$, nutrient content in the soil and altitude. According to Hoshizaki and Moran (2001), ferns in the tropics generally require a temperature range between 21 $27^{\circ} \mathrm{C}$ to grow. Laily (2012) stated that the height of the place is one of the factors that influence the growth of ferns. So, it is suspected that the growth and development of the plants at different altitudes, will be different. As a result, a series of processes of metabolism in these plants will also be disrupted and the compounds produced will also be different.

Histiopteris incisa belongs to Dennstaedtiaceae family which is also known as the batwing ferns and is typical primary colonizer of disturbed ground such as in land clearings caused by tree falls, or in a forest that has been seriously damaged by browsing animals (De Lange PJ. 2020). The family Dennstaedtiaceae consists of 10 genera with about 265 pantropical and, occasionally, boreal or temperate regions species (PPG I 2016). Based on research results in its natural habitat, $H$. incisa was spread well in different locations with different height but found more in open areas. The temperatures at an altitude of $700 \mathrm{~m}$. asl range between was $25.0-28.6^{\circ} \mathrm{C}$, and at $1,000 \mathrm{~m}$. asl was $24.1-29.8^{\circ} \mathrm{C}$. From the results obtained states that environmental parameters at an altitude of $700 \mathrm{~m}$. asl with $1,000 \mathrm{~m}$. asl is not much different and the range of abiotic factors is suitable as H.incisa habitat. It was observed that the phenol content at an altitude of $1,000 \mathrm{~m}$. asl. is higher. This may be caused by the presence of abiotic environmental factors such as altitude, light intensity, soil $\mathrm{pH}$, humidity, and soil temperature. Environmental factors certainly will affect plant growth and development, thus also will regulate the biosynthesis of secondary metabolites. Phenolic constituents as one of the secondary metabolites induced antioxidant activity that affects $\mathrm{IC}_{50}$ from $H$. incisa leaves extract. Both extracts were classified as having strong antioxidants.

Praptosuwiryo et al. (2019) found that $N$. biserrata tends to grow abundantly on palm trees plantation especially on upper zone of trees. Besides, it useful to maintain the land humidity and keep the soil from lack of water (Ariyanti 2016). In Mount Halimun Salak we found $N$. biserrata at two different heights of 700 and $1000 \mathrm{~m}$.asl. Characteristics of the $N$. biserrata are located on the scales on the stip and the location of the sorus close to the edge of the medial pinna. It has a narrow and thinly spread shell morphology, the edges of shell have fine hair (De winter 2003). The measurement results of one of the environmental factors, humidity show differences at two heights, this is because at $700 \mathrm{~m}$. asl. was covered by pine tree vegetation which causes the temperature to decrease due to lack of light intensity so that the humidity increases, while at an altitude of $1,000 \mathrm{~m}$ asl. the measurement parameter is more open which causes the plant to be directly exposed to sunlight which will affect the humidity value. The determination of phenolic levels of $N$. biserrata showed that an altitude of $700 \mathrm{~m}$. asl. higher than $1000 \mathrm{~m}$ altitude and affected to antioxidant activity and $\mathrm{IC}_{50}$.

Selaginella willdenowii grows both in shaded and open forest areas in Gunung Malang Village, Gunung Halimun Salak National Park. However, basically, most of Selaginella grow under the forest canopy and is protected from direct sunlight, spreads well in tropical forest areas and thrives on the forest surface. In terms of morphology, the leaves of $S$. willdenowii that grow in shaded areas have a bright blue color, while those that grow in open areas are brownish-yellow (Figure 3); it could possibly because it can modify chloroplasts to encourage the exploitation of sunlight by forming non-optical structures which are schemochromic tydall blue colored, so that $S$. willdenowii have a green color with a blue flame when it grows in shaded place (Fox and Wells 1971). Based on adequate population, the range of environmental factors obtained indicates conditions suitable for $S$. willdenowii growth. The phenol content in the shaded forest is lower than the phenol content in the open forest. Irradiation factors will affect plant growth and development, thereby regulating the biosynthesis of secondary metabolites (Hyun et al. 2017). Antioxidant activity also shows results that are in line with phenol levels.

In conclusion, this research shows that all ferns tested gave significant antioxidant activity and was influenced by environmental factors. This research is also expected to be the initial data in the search for sources of compounds that are pharmacologically efficacious.

\section{ACKNOWLEDGEMENTS}

Authors would like to acknowledge the Research Institution of Universitas Muhammadiyah Prof. Dr. HAMKA (UHAMKA), Jakarta, Indonesia for supporting this work.

\section{REFERENCES}

Anggia V, Bakhtiar A, Arbain D. 2015. Chemical constituents and antibacterial activities of leaves of Sumatran king fern (Angiopteris evecta G. Forst Hoffm.). Jurnal Farmasi Indonesia 7 (4): 195-202.

Ariyanti M. 2016. Peranan Tanaman Penutup Tanah Nephrolepis biserrata pada Teknik Konservasi Tanah dan Air terhadap Neraca Air di Perkebunan Kelapa Sawit. [Thesis]. Sekolah Pascasarjana, Institut Pertanian Bogor. Bogor. [Indonesian]

Babbar N, Oberoi HS, Sandhu SK. 2015. Therapeutic and nutraceutical potential of bioactive compounds extracted from fruit residues. Crit 
Rev Food Sci Nutr 55: 319-337. DOI 10.1080/10408398.2011.653734.

Balangcod TD, Ashlyn KDB. 2011. Ethnomedicinal knowledge of plants and healthcare practices among the Kalanguya tribes in Tinoc, Ifugao, Luzon, Philipines. Indian J Tradit Knowl 10 (2): 227-238.

Dai X, Chunfa C, Zhongyang Li, Xuexiong W. 2020. Taxonomic, phylogenetic, and functional diversity of ferns at three differently disturbed sites in Longnan County, China. Diversity 12 (135). DOI: $10.3390 / \mathrm{d} 12040135$

De Lange PJ. 2020: Histiopteris incisa fact sheet. New Zealand Plant Conservation Network. www.nzpcn.org.nz/flora/species/histiopterisincisa/

De Winter WP, Amoroso VB. 2003. Plant Resources of South-East Asia No. 15. Cryptogams: Ferns and Fern Allies. Backhuys Publishers, Leiden.

Elfahmi, Woerdenbag H, Kayser O. 2014. Jamu: Indonesian traditional herbal medicine towards rational phytopharmacological use. J Herbal Med 4 (2): 51-73. DOI: 10.1016/j.hermed.2014.01.002.

Fox DL, Wells JR. 1971. Schemochromic blue leaf-surfaces of Selaginella. Am Fern J 61 (3): 137-139.

Hoshizaki BJ, Moran RC. 2001. Fern Grower"s Manual. Timber Press, Portland, OR.

Hyun JJ, Seung JL, Cha YK, Joo TH, Jung HC, Jee HP, Seung WL, Mun CR. 2017. Effect of sunlight radiation on the growth and chemical constituents of Salvia plebeia R.Br. Molecules 22: 1279. DOI: 10.3390 .

Keller HA, Prance GT. 2015. Review: The ethnobotany of ferns and lycophytes. Fern Gaz 20 (1): 1-13.

Koudouvo K, Karou DS, Kokou K, Essien K, Aklikokou K, Glitho IA, Simpore J, Sanogo R, De Souza C, Gbeassor M. 2011. An ethnobotanical study of antimalarial plants in Togo Maritime Region. J Ethnopharmacol 134 (1): 183-190. DOI: 10.1016/j.jep.2010.12.011.

Laily AN, Suranto, Sugiyarto. 2012. Characterization of Carica pubescen on the Dieng Plateau, Central Java based on morphological properties, antioxidant capacity, and protein band patterns. Nusantara Biosci 4 (1): 16-21. DOI: 10.13057/nusbiosci/n040104.

Molyneux P. 2004. The use of stable free radical diphenylpicrylhydrazyl (DPPH) for estimating antioxidant activity. Songklanakarin J Sci Technol 26 (2): 211-219.

PPG I. 2016. A community-derived classification for extant lycophytes and ferns. J Syst Evol 54 (6): 563-603. DOI: 10.1111/jse.12229
Praptosuwiryo TN, Sumanto, Ria CN. 2019. Diversity and host preferences of ferns and lycopods epiphytes on palm trees. Biodiversitas 20 (12): 3731-3740. DOI: 10.13057/biodiv/d201236

Purnawati U. 2014. Exploration of Ferns (Pteridophyta) in the Nature Reserve Area of Mandor, Landak Regency. [Thesis]. Program Studi Biologi, FMIPA, Universitas Tanjungpura, Pontianak. [Indonesian]

Radhika NK, Sreejith PS, Asha VV. 2010. Cytotoxic and apoptotic activity of Cheilanthes farinosa (Forsk.) Kaulf. against human hepatoma, Hep3B cells. J Ethnopharmacol 128: 166-171. DOI: 10.1016/j.jep.2010.01.002.

Raimana H, Taivini T, Jean PB, René L. 2011. Ferns: from Traditional Uses to Pharmaceutical Development, Chemical Identification of Active Principles. Springer Science and Business Media, Llc., New York. DOI: 10.1007/978-1-4419-7162-3_23.

Rani D, Khare PB, Dantu PK. 2010. In vitro antibacterial and antifungal properties of aqueous and non-aqueous frond extracts of Psilotum nudum, Nephrolepis biserrata and Nephrolepis cordifolia. Indian J Pharm Sci 72 (6): 818-822. DOI: 10.4103/0250-474X.84606

Roos M. 1996. Mapping the world's pteridophytes diversity-systematics and floras. In: Camus JM, Gibby M, Johns RJ (eds.). Pteridology in Perspective. Royal Botanic Gardens, Kew, UK.

Setyawan AD, Supriatna J, Darnaedi D, Rokhmatuloh, Sutarno, Sugiyarto. 2016. Diversity of Selaginella across altitudinal gradient of the tropical region. Biodiversitas 17 (1): 384-400. DOI: 10.13057/biodiv/d170152.

Silva GL, Chai H, Gupta MP, Farnsworth NR, Cordell GA, Pezzuto JM, Beecher CWW, Kinghorn AD. 1995. Cytotoxic biflavonoids from Selaginella willdenowii. Phytochemistry 40 (1): 129-134. DOI: 10.1016/0031-9422(95)00212-p

Stankovic MS, Niciforovic N, Topuzovic M, Solujic S. 2011. Total phenolic content, flavonoid concentrations and antioxidant activity, of the whole plant and plant parts, extracts from Teucrium montanum $\mathrm{L}$. Var. montanum, F. supinum (L.) Reichenb. Biotechnol Biotechnol Equip 25 (1): 2222-2227. DOI: 10.5504/bbeq.2011.0020.

Steenis CG. 2013. Flora. PT. Balai Pustaka, Jakarta. [Indonesian]

Syafni N, Putra DP, Arbain D. 2012. 3,4-Dihydroxybenzoic acid and 3,4dihydroxybenzaldehyde from the fern Trichomanes chinense L.; isolation, antimicrobial and antioxidant properties. Indon J Chem 12 (3): 273-278.

Tiwari P, Kumar B, Kaur M, Kaur G, Kaur H. 2011. Phytochemical screening and extraction: a review. Intl Pharm Sci 1 (1): 98-106. 